New Zealand Journal of Marine and Freshwater Research

\title{
DNA barcode, taxonomic and ecological notes for the identification of the invasive amphipod Monocorophium acherusicum (Costa, 1851)
}

Mariano J. Albano, Carlos Rumbold, Ignacio L. Chiesa, Guadalupe Vazquez, Eduardo D. Spivak \& Sandra M. Obenat

To cite this article: Mariano J. Albano, Carlos Rumbold, Ignacio L. Chiesa, Guadalupe Vazquez, Eduardo D. Spivak \& Sandra M. Obenat (2018): DNA barcode, taxonomic and ecological notes for the identification of the invasive amphipod Monocorophium acherusicum (Costa, 1851), New Zealand Journal of Marine and Freshwater Research, DOI: 10.1080/00288330.2018.1469514

To link to this article: https://doi.org/10.1080/00288330.2018.1469514

曲 Published online: 10 May 2018.

Submit your article to this journal $₫$

Q View related articles $\sqsubset$

View Crossmark data ¿ 


\title{
DNA barcode, taxonomic and ecological notes for the identification of the invasive amphipod Monocorophium acherusicum (Costa, 1851)
}

\author{
Mariano J. Albano ${ }^{a}$, Carlos Rumbold ${ }^{b}$, Ignacio L. Chiesa ${ }^{a}$, Guadalupe Vazquez ${ }^{b}$, \\ Eduardo D. Spivak ${ }^{b}$ and Sandra M. Obenat ${ }^{b}$ \\ ${ }^{a}$ Centro Austral de Investigaciones Científicas (CADIC-CONICET), Ushuaia, Tierra del Fuego, Argentina; \\ b Instituto de Investigaciones Marinas y Costeras (IIMyC), Facultad de Ciencias Exactas y Naturales, Universidad \\ Nacional de Mar del Plata and Consejo Nacional de Investigaciones Científicas y Tecnológicas Mar del Plata, \\ Buenos Aires, Argentina
}

\begin{abstract}
We report the occurrence of the invasive amphipod Monocorophium acherusicum in Mar del Plata port, Argentina, using morphological and molecular analysis and estimated mean abundance to detect monthly variations of this population. We compared $M$. acherusicum morphology with that of $M$. insidiosum and Crassicorophium bonelli, the two most similar locally occurring species, to establish the diagnostic characteristics for the correct identification of them; moreover, we provide some taxonomic notes about others corophiids regionally distributed. $M$. acherusicum were collected in a subtidal biofouling community and its mean abundance was maximum in summer. In the molecular analysis, the maximumlikelihood tree showed that specimens from Mar del Plata were clustered with $M$. acherusicum specimens from GenBank and Boldsystems. We support and confirm the species identity in Mar del Plata port using DNA barcoding and with taxonomic methods.
\end{abstract}

\section{ARTICLE HISTORY}

Received 11 December 2017

Accepted 22 April 2018

\section{ASSOCIATE EDITOR}

Conrad Pilditch

\section{KEYWORDS}

Molecular analysis; corophiids; crustaceans; nonindigenous species; Mar del

Plata port; Argentina

\section{Introduction}

Biological invasions are a common phenomenon in marine ecosystems and their frequencies have increased in recent time, particularly in environments associated with international trade ports (eg Cohen and Carlton 1995; Reise et al. 1998; Ruiz et al. 2000; Orensanz et al. 2002; Hewitt et al. 2004; Kerckhof et al. 2007; Schwindt et al. 2014). The main pathway for the introduction of marine invasive species to ports around the world has been shipping through biofouling on the hull of the vessels, ballast water and the sea chest (ie intake chambers in vessel hulls) (Gollasch 2002; Godwin 2003; Hewitt et al. 2004; Coutts and Dodgshun 2007). Invasive species may homogenise the global biodiversity (Olden and Poff 2004), favour the introduction of parasites and diseases (Kuris and Culver 1999), compete with native organisms for food and space, and in turn may act as easily accessible food items for a range of predatory fish and invertebrates (Griffiths et al. 2009). 
One of the major consequences of coastal development and urbanisation is the addition of an artificial hard-bottom structure to coastal areas, including seawalls, dykes, breakwaters, jetties and offshore platforms (Airoldi et al. 2009). Port areas concentrate a variety of such structures that support many different organisms (Glasby 1999; Connell 2001), and it is known that artificial and natural habitats are not equally colonised by fouling species (Connell 2001). Artificial structures often provide habitat for exotic species (Floerl and Inglis 2003) and, consequently, ports may act as recipients and dispersal areas for these organisms. Monitoring these areas constitutes an early detection mechanism of these species.

Amphipods are peracarid crustaceans widely represented in coastal and shelf communities throughout the oceans, being an important link between benthic and demersal food webs (De Broyer and Jażdżewski 1996; Dauby et al. 2003). Among them, corophiids (Corophiidae) are tube-dwelling amphipods that inhabit soft sediments and hard surfaces. As part of biofouling they are easily transported great distances, either synanthropically or naturally, via their settlement on ship bottoms or drifting debris, respectively (Thiel and Gutow 2005; Noël 2011). Consequently, a number of species are now virtually cosmopolitan, at least within their range of environmental tolerance, and it is often difficult to determine their original distributions. An additional problem affecting the accuracy of the known distributions for these taxa lies in the fact that they are superficially quite similar to one another and many misidentifications exist in the literature (LeCroy 2004). The invasion of exotic amphipods is considered an important threat to biodiversity because the explosive growth in their population size may affect community composition and ecosystem processes (Conlan 1994). An accurate identification of invasive species is essential to determine the potential effects on local populations. In this context, Monocorophium acherusicum (Costa, 1951) is considered a global invasive species due to their wide distribution around the world (Griffiths et al. 2009; Ruiz et al. 2011). This species is most probably originated in the eastern North Atlantic and was introduced, by shipping and other means, to all protected marine coasts between $50^{\circ} \mathrm{N}$ and $50^{\circ} \mathrm{S}$ latitude (LeCroy 2004; Chapman 2007). It is a dorsoventrally flattened and yellowish-brown species that occurs subtidal on sediments or where silt and detritus accumulate among biofouling organisms such as algae, ascidians and bryozoans, and man-made installations (eg wharf pylons, rafts and buoys). It feeds by grazing on bacteria, on sediment particles, or on organic matter suspended in the water column. It builds conspicuous, fragile Ushaped tubes of silk, mud and sand particles, and can reach high abundances and tolerate a wide range of salinities (Inglis et al. 2006).

In Argentina, several species of corophiids have been recorded (López Gappa et al. 2006), including M. acherusicum, M. insidiosum (Crawford 1937) and Crassicorophium bonellii (Milne Edwards, 1830). The superficial morphological similarities of these species (see Crawford 1937; Chapman 2007) made the identification of specimens difficult. $M$. acherusicum was recorded as an exotic species in various ports of Argentina (Albano et al. 2013; Schwindt et al. 2014). However, none of these studies has focused on both morphological and molecular analyses to confirm the presence of this invasive species. Furthermore, the identification difficulties mentioned have led to an erroneous report of $M$. acherusicum as $M$. insidiosum (see Albano and Obenat 2009). In recent years, the use of molecular taxonomy has proved to be a powerful tool for solving the misidentification of morphologically similar species (eg Bucklin et al. 2007; Hou et al. 2007; Bilgin et al. 2015; Rumbold et al. 2015a). It was also has been used to document species introductions (Bourlat et al. 2013). 
The population dynamics of amphipods M. acherusicum and Ericthonius punctatus from Mar del Plata harbour has been done by Rumbold et al. (2016). They found that both species showed a seasonal pattern characterised by high densities in warmer months, related to the highest reproductive activity and the increase of recruitment in summer and early autumn, as well as lower densities in the cold season.

As part of an ongoing project for monitoring and identification of native and exotic benthic invertebrates within the Mar del Plata port (Argentina), using DNA barcoding, in this paper we report the occurrence of the invasive amphipod M. acherusicum using both morphological and molecular analysis. Also, we estimated mean abundance in order to detect monthly variations of this population. Finally, we compared M. acherusicum, $M$. insidiosum and $C$. bonellii, in order to highlight the taxonomic characters that serve as tools for the correct identification of these species, and also we provide some taxonomic notes about other corophiids distributed regionally.

\section{Material and methods}

\section{Study area}

Specimens of Monocorophium acherusicum were collected from marinas of the Club Naútico, Mar del Plata port, 38 $02^{\prime} 29^{\prime \prime} \mathrm{S}, 57^{\circ} 32^{\prime} 16^{\prime \prime} \mathrm{W}$, Argentina, SW Atlantic (Figure 1). Mar del Plata is a seaport where different products are exported overseas and touristic activities are developed. The port is a semi-enclosed area, protected by two artificial breakwaters (North and South) made of orthoquartzite blocks that delimit an approximately 300-metre wide mouth. The mean water depth is $5 \mathrm{~m}$, ranging between 3 and $12 \mathrm{~m}$. A navigational channel is maintained to a depth of $10 \mathrm{~m}$ (Rivero et al. 2005). Mean monthly water temperature ranges from $9.3^{\circ} \mathrm{C}$ in July (austral winter) to $20.9^{\circ} \mathrm{C}$ in February (austral summer), (data obtained from Argentine Oceanographic Data Center, CEADO). In the inner sector of the port, silty-clay sediments with higher levels of organic matter and phytopigments, are dominated by opportunistic nematodes and Capitella sp., usually associated worldwide to polluted habitats (Albano et al. 2013).

\section{Sampling}

\section{Field sampling and laboratory procedures}

In order to determine the mean abundance of M. acherusicum, from April 2007 to March 2008, the macrofouling community living on wooden piles on the inner side of the marinas was extracted using SCUBA diving at a depth of 3-4 m. Each month, six independent replicates $(N=6)$ were collected at random using an epibenthic net (mesh $0.5 \mathrm{~mm})$ galvanised wire frame $25 \times 25 \mathrm{~cm}\left(0.0625 \mathrm{~m}^{2}\right)$ and scraping with metal spatula, from different vertical wooden piles. Samples were fixed in $96 \%$ alcohol. In the laboratory, samples were sieved through a $0.35 \mathrm{~mm}$ mesh and organisms were sorted and counted using a stereomicroscope.

\section{Morphological and genetic identification}

The material used for taxonomic identifications were collected among the biofouling community of the marinas using spatula, during April, July and November 2014 and February 


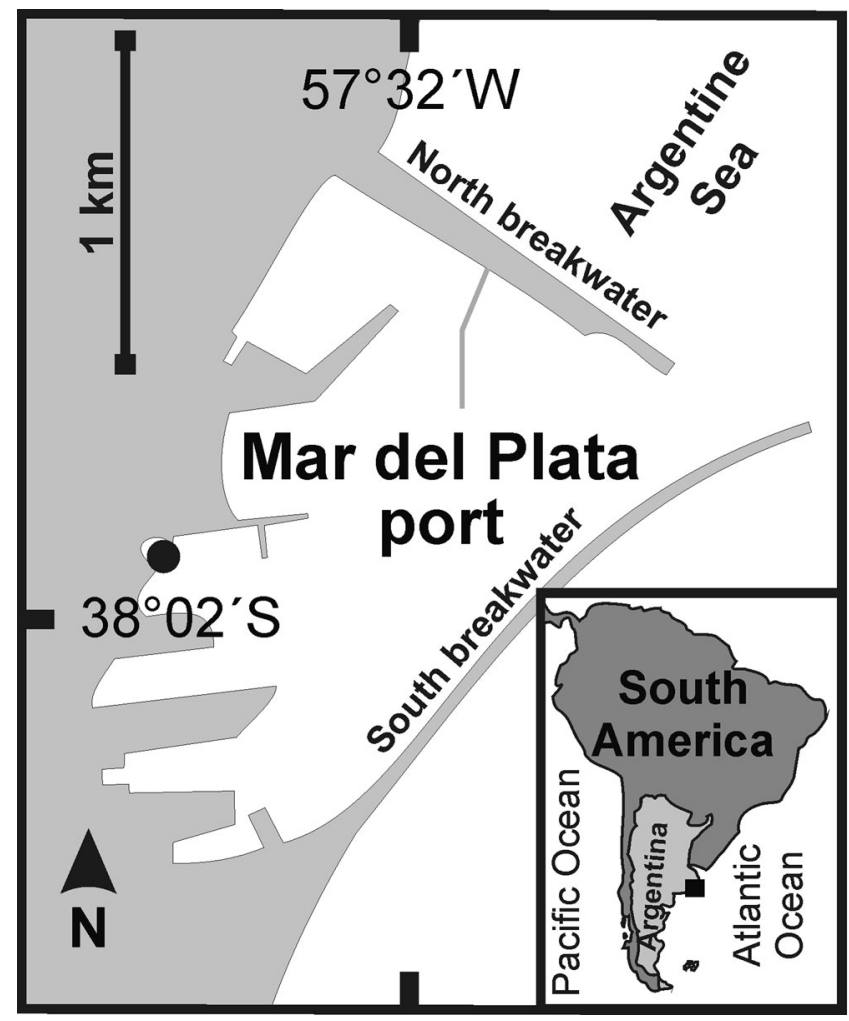

Figure 1. Map of the Mar del Plata port, Argentina, showing the sampling site (0).

2015. Amphipods of genus Monocorophium Bousfield and Hoover, 1997 were separated from the extracted material using a stereoscopic microscope and identified with taxonomic guides (LeCroy 2004; Chapman 2007). Adult specimens of M. acherusicum were measured and dissected in order to determine morphologically the sexes. To confirm the species identification through genetic analysis, a tissue sample was obtained from three adult specimens (1 male, 1 non-ovigerous and 1 ovigerous female) collected on 21st November, from which a partial fragment of the barcode gene cytochrome c oxidase I was sequenced. DNA extraction, PCR amplification, PCR product purification and sequencing were conducted following the protocols of the Canadian Centre for DNA Barcoding (CCDB protocols http://ccdb.ca/docs/; see also Ivanova et al. 2006, using the universal primers HC02198 (5' TAA ACT TCA GGG TGA CCA AAA AAT CA-3'), and LCO1490 (5'-GGT CAA CAA ATC ATA AAG ATA TTGG-3') (Folmer et al. 1994).

\section{Statistical and molecular analysis}

To assess whether there were differences in monthly variation in mean abundances (no. of individuals per $\mathrm{m}^{2}$ ) in the population, of adult males and females, a univariate analysis were performed. The null hypothesis of no difference in the monthly average abundances of M. acherusicum was assessed by one-way analysis of variance (ANOVA; eg Underwood 1997) considering 'Month' as the fixed factor. Data were previously log-transformed to carry out the statistical analysis. Following Underwood (1997), post-hoc comparisons were 
performed with Student Newman Keuls (SNK) tests. ANOVA was performed using SigmaPlot 11.0.

To carry out the molecular identification of specimens, the public COI sequence obtained from Barcode of Life (BOLD, http://www.barcodelife.org) were used to make the BIN assignment (barcode index number) and were compared against GenBank (http://www.ncbi.nlm.nih.gov/GenBank) using the BLAST algorithm. BLAST provides a statistical value for each sequence, called the E-value, which describes the number of hits one can 'expect' to see by chance when searching a database. E-values closer to zero indicate a significant match. A phylogenetic analysis based on the construction of a maximum-likelihood tree was conducted to validate the identity of our material and the Monocorophium spp. from GenBank. For this phylogenetic analysis, additional COI sequences of Monocorophium spp. were retrieved from GenBank and BOLD (for species name and accession numbers, see Figure 5). The COI sequence of the isopod Sphaeroma serratum (Fabricius, 1787) was used as outgroup. The COI sequences were aligned using BioEdit v.7.08.0 software (Hall 1999) through the Clustal W method (Thompson et al. 1994) and were verified by sight. A phylogenetic tree was inferred in MEGA v6 (Tamura et al. 2013); http://www.megasoftware.net/) and was evaluated with a bootstrap test with 1000 replications.

\section{Results}

\section{Systematics}

Order Amphipoda Latreille, 1816

Suborder Senticaudata Lowry and Myers, 2013

Family Corophiidae Leach, 1814

Subfamily Corophiinae Leach, 1814

Tribe Corophiini Leach, 1814

Monocorophium acherusicum (Costa 1853)

(Figure 2)

\section{Examined material}

Club Náutico de Mar del Plata; among biofouling community, <1 m deep; April 2014, 8 males and 10 ovigerous females; July 2014, 1 male; November 2014, 1 male, February 2015, 1 male; specimens collected by M. J. Albano.

\section{Diagnosis}

Male of $M$. acherusicum (Figure 2A-F) has a minute, deeply recessed rostrum; antenna 1, peduncle articles 1 and 2 with several long distal setae on dorsomedial margin (also present in female), peduncle article 1 without robust setae on dorsomedial margin and ventromedial margin without process (may have irregular crenulations in large male); antenna 2, enlarged in adults, peduncle articles sparsely setose, peduncle article 4 without ventromedial processes, ventrolateral distal angle with 1 large acute process, article 5 with proximal small process on ventromedial margin and broad distal process; 


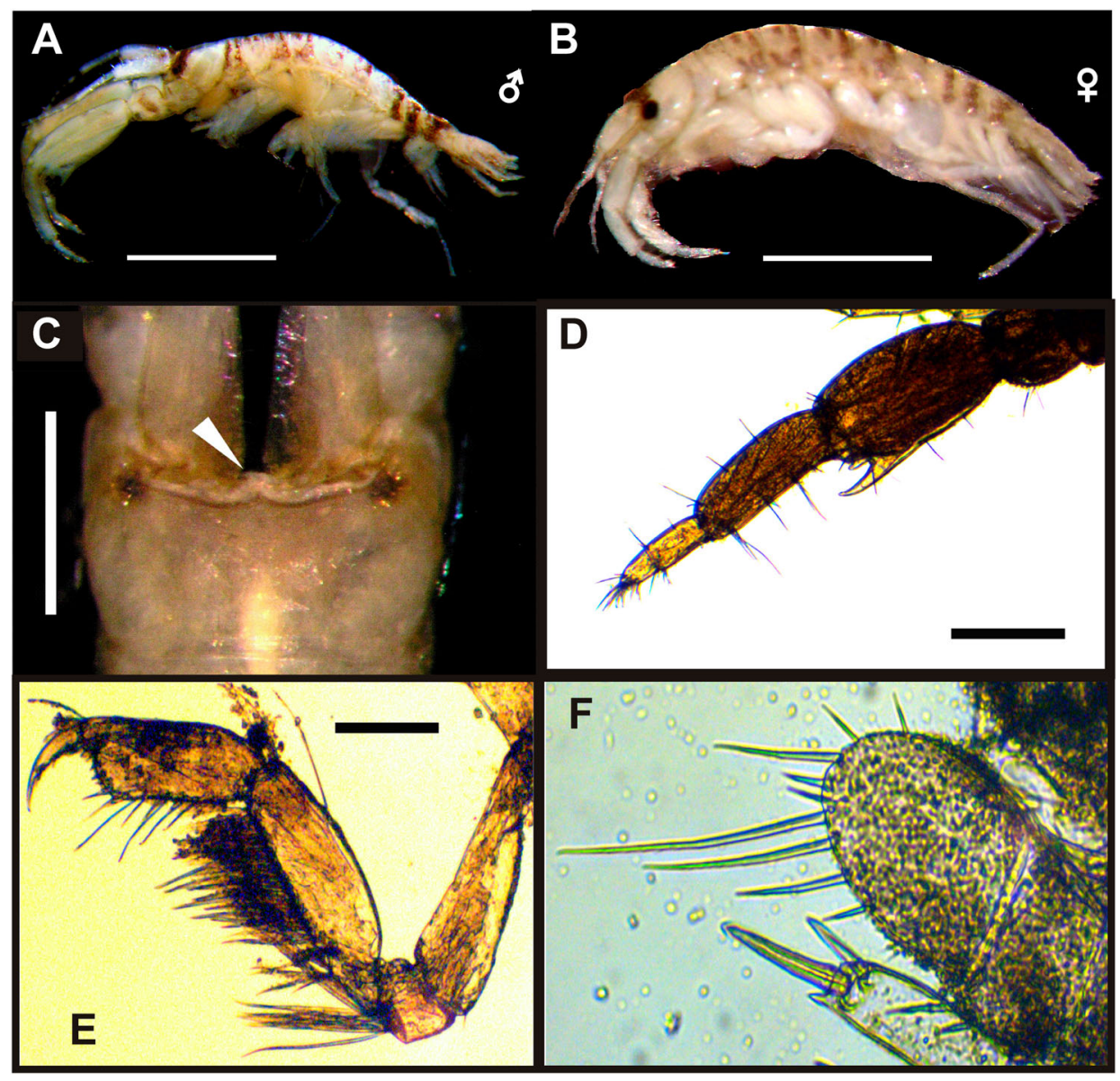

Figure 2. Monocorophium acherusicum from Mar del Plata port. A-B, lateral view of adult male and female; $\mathbf{C}$, dorsal view of head of male; $\mathbf{D}$, male antenna 2; $\mathbf{E}$, male gnatophod 1; $\mathbf{F}$, uropod 3. Scale bars: A-B, C and F, $0.05 \mathrm{~mm} ; \mathbf{D}, 0.5 \mathrm{~mm} ; \mathbf{E}, 0.1 \mathrm{~mm}$.

gnathopod 1, dactyl extending well beyond palmar angle; gnathopod 2, dactyl with 2 teeth on posterior margin; pereopod 3 and 4, anterior margin of basis lacking long setae; pereopod 7 not elongate; urosomites fused, with distinct lateral notch; uropod 1, peduncle with 2-5 robust setae on medial margin, and 6-7 on outer margin, rami short; uropod 2 , outer margin of inner ramus with robust setae; uropod 3, ramus sub circular, approximately as long as wide. Female, antenna 1, peduncle article 1 with several robust setae on dorsomedial and ventral margin; antenna 2 peduncle articles 3-5 with several robust setae on ventral margin, article 5 not distally produce, with several long simple setae. See Bousfield (1973); Lincoln (1979); Bousfield and Hoover (1997) and LeCroy (2004).

\section{Distribution}

M. acherusicum is virtually cosmopolitan in temperate and tropical waters (LeCroy 2004). It was first described from Italy (Type locality: lake Fusaro, near Naples) by Costa (1851). Bousfield and Hoover (1997) suggested that it most probably originated in the eastern North 
Table 1. First records of Monocorophium acherusicum according to country or region, site where it was found and the status.

\begin{tabular}{|c|c|c|c|c|}
\hline Country or Region & Site & $\begin{array}{l}\text { First } \\
\text { record }\end{array}$ & Status & References \\
\hline North America (Atlantic coast) & Unspecified & 1818 & $\mathrm{~N}$ & $\begin{array}{l}\text { Say (1818) (probably described as Podocerus } \\
\text { cylindricus, Shoemaker (1934)) }\end{array}$ \\
\hline $\begin{array}{l}\text { Europe / North Africa } \\
\text { (Mediterranean sea) }\end{array}$ & Unspecified & 1851 & NIS & $\begin{array}{l}\text { Costa (1853); Della Valle (1893); Stebbing } \\
\text { (1906) }\end{array}$ \\
\hline New Zealand & Harbour & 1880 & NIS & Chilton (1921) (as C. crassicorne) \\
\hline North Africa (Atlantic coast) & Unspecified & 1892 & $\mathrm{C}$ & Chevreux $(1911,1935)$ \\
\hline United States (Pacific coast) & Harbour & 1905 & NIS & Cohen and Carlton (1995) \\
\hline China & Unspecified & 1906 & NIS & Stebbing (1906) \\
\hline Red Sea & Unspecified & 1909 & NIS & Walker (1909) \\
\hline South Africa & Harbour & 1915 & NIS & Barnard (1916) \\
\hline Australia & Unspecified & 1921 & NIS & Hayes et al. (2005) \\
\hline Europe (Atlantic coast) & Unspecified & 1928 & C & Schellenberg (1928); Crawford (1937) \\
\hline Eastern Africa (Tanzania) & Unespecifiesd & 1928 & NIS & Schellenberg (1928) \\
\hline Brazil & Unspecified & 1934 & NIS & Shoemaker (1934) \\
\hline Hawaiian Is. & Unspecified & 1947 & NIS & Shoemaker (1947) \\
\hline Japan & $\begin{array}{l}\text { Artificial rocks } \\
\text { outcrops }\end{array}$ & 1955 & NIS & Irie (1956) \\
\hline Argentina & Unspecified & 1969 & NIS & USNM \#127701 \\
\hline India & Harbour & 1969 & NIS & Sivaprakasam (1970) \\
\hline Chile & $\begin{array}{l}\text { Aquaculture } \\
\text { facility }\end{array}$ & 2009 & NIS & Schultheiss (2009) \\
\hline
\end{tabular}

NIS: non-indigenous species; N: native; C: cryptogenic.

Atlantic: France, Belgium and England. It has been recorded in Argentina (Albano et al. 2013; Schwindt et al. 2014, Rumbold et al. 2016; Nuñez Velazquez et al. 2017), Chile (Thiel and Hinojosa 2009), Australia (Chilton 1921; Hayes et al. 2005), New Zealand (Chilton 1921), Japan (Irie 1956; Hirayama 1995), South Africa (Barnard 1916), the Pacific coasts of North America (Wasson et al. 2001; Ruiz et al. 2011), and Black Sea, North Pacific Ocean, Indian Ocean, Eastern and South China Seas (Molnar et al. 2008). Other authors have suggested that it is cryptogenic (crypt-, Greek, Kryptos, secret; -genic, Latin, genic, origin), as species that is not demonstrably native or introduced (Carlton 1996) in Brazil (Neves et al. 2007; Neves and Rocha 2008), Atlantic Europe (UK to Portugal) (Noël 2011), and the east and northwest coasts of the USA (Ruiz et al. 2011). On the other hand, Neves and Rocha (2008) hypothesised that $M$. acherusicum could have originated from the southern hemisphere in general, and it have been moved to the northern hemisphere by the sailing vessels of the Europeans from the 16th to 18th centuries. Table 1 and Figure 3 show the global distribution of M. acherusicum. However, due to the tendency for misidentifications among corophiid species, as well as the age of some records, this distribution should be taken with caution.

\section{Abundance}

The mean abundance of $M$. acherusicum showed statistical differences (ANOVA, $F=2.78$, $d f=11, P=.006)$. Subsequent analyses revealed that the maximum average abundance of M. acherusicum was during the austral summer, with a peak in December (SNK test). The mean abundance was $9209 \pm 142,004 \mathrm{ind} / \mathrm{m}^{2}$ and varied seasonally, the lowest values were recorded during winter-spring $\left(1 \pm 0.34 \mathrm{ind} / \mathrm{m}^{2}\right)$ while from the rest of the summer the mean density remained unchanged (between 15,000 and $30,000 \mathrm{ind} / \mathrm{m}^{2}$; SNK test, $P>.05$; Figure 4). 


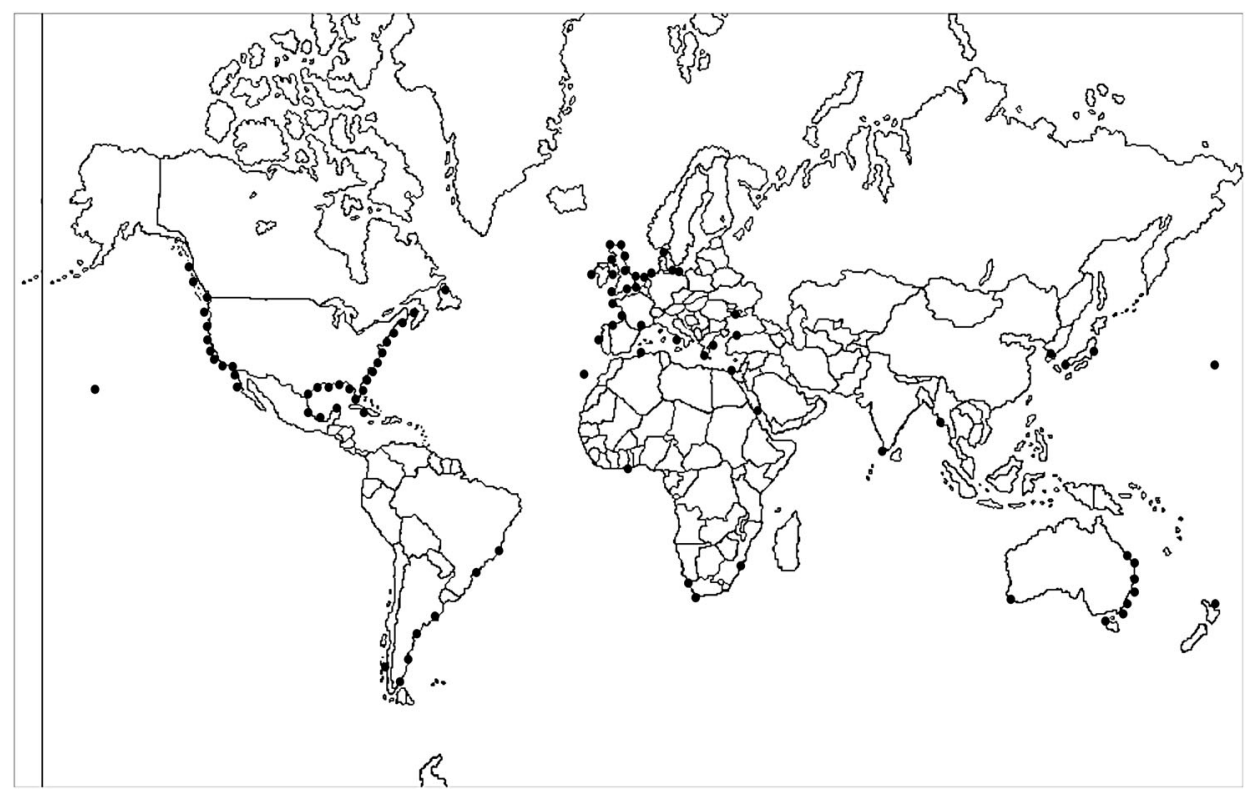

Figure 3. Monocorophium acherusicum world distribution.

\section{Molecular analysis}

The 658 bp COI sequences obtained from the three specimens showed between $98.37 \%$ and 99.85\% similarity with a mitochondrial COI sequence of $M$. acherusicum from Atlantic and Pacific coast of United States (n: 15), Germany (North Sea, n: 5) and Portugal (n: 1) (for accession numbers see Figure 5; in all cases, E-value: 0 ), confirming the species identity (BIN assignment: BOLD AAU1637). The maximum-likelihood (ML) tree showed that specimens from Mar del Plata port were clustered with $M$. acherusicum specimens from GenBank and Boldsystems (Figure 5). In addition, all the available sequences of Monocorophium spp in BOLD and Genbank were also segregated by species, registering a clear differentiation between $M$. acherusicum (n: 24), M. sextonae (n: 5) and M. insidiosum (n: 9); while the cryptic species Crassicorophium bonelli (n: 1) revealed genetic differences with Monocorophium spp.

\section{Comparison with other corophiids distributed regionally}

The males of Monocorophium insidiosum, the other species belonging to this genus present in Mar del Plata port, are recognisable by the very elongate and slender rostrum, which is minute in $M$. acherusicum (see Figure 2C and Figure 6). In addition, M. acherusicum differs from $M$. insidiosum by the following features (those of $M$. insidiosum in parentheses): antenna 1 of males, peduncle article 1 without process (ventromedial margin with a short and blunt proximal process); antenna 2 of males, peduncle article 5 with proximal process on ventromedial margin (without proximal process); gnathopod 1, dactyl extending well beyond the palmar angle (barely extending); gnathopod 2, dactyl with 2 teeth on posterior margin (with 3 teeth); pereopod 3 and 4, anterior margin of basis without long setae (moderately to strongly setose); uropod 2, outer margin of inner ramus with robust setae (lacking setae) (see Bousfield and Hoover 1997; LeCroy 2004). 


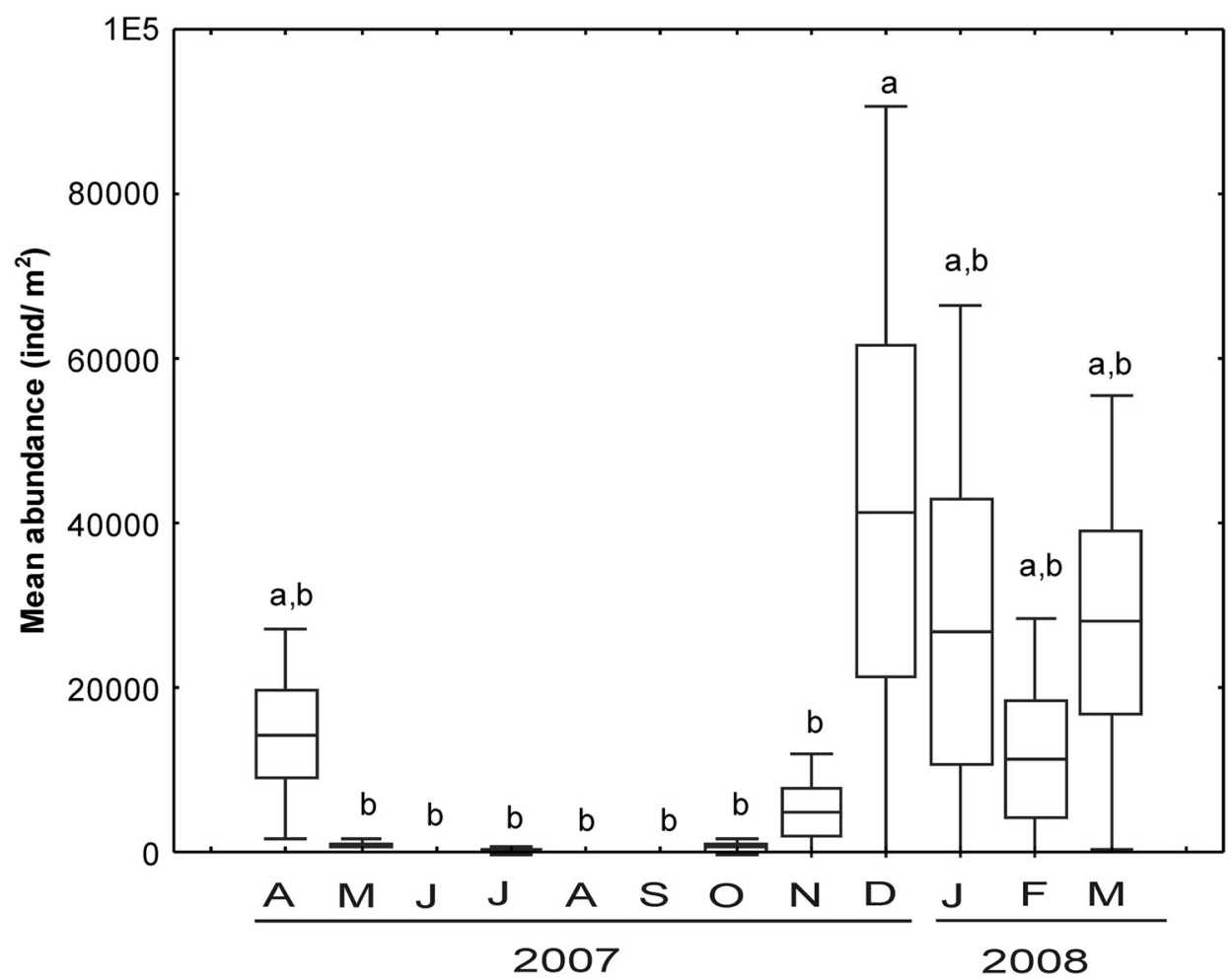

Figure 4. Monthly variations in the mean abundance of the exotic amphipod Monocorophium acherusicum in the Mar del Plata port during April 2007 to March 2008. Boxes indicate the \pm SE, vertical lines are $\pm \mathrm{SD}$ and the horizontal line the average. Different letters indicate differences between months according to SNK test (ANOVA: $p<.05$ ).

In the Argentine Sea, M. insidiosum has been recorded from the coast of Buenos Aires Province (Ieno and Bastida 1998), including Mar del Plata port (Rivero et al. 2005; Lopez Gappa et al. 2006; Albano et al. 2013; Carcedo et al. 2015), as well as other ports of Patagonia: San Antonio Este, Puerto Madryn, Puerto Deseado, San Julián and Ushuaia (Sueiro et al. 2012; Schwindt et al. 2014; Martin et al. 2015).

Besides $M$. insidiosum, two other species of this genus are distributed regionally: M. cylindricum (Say, 1818) has been cited from Malvinas/Falkland Islands, and M. josei Valério-Berardo and de Souza, 2009 was described based on material collected in southern Brazil (see López Gappa et al. 2006; Valério-Berardo and de Souza 2009).

After reviewing the specimens of $M$. cylindricum deposited in the U.S. National Museum, Shoemaker (1934) found that all were identical with M. acherusicum (see also Crawford 1937, p. 591; Shoemaker 1947, p. 53). Later on, based on their overlap distributions, and although the type material of $M$. cylindricum had been apparently lost, Bousfield and Hoover (1997) suggested that M. cylindricum was synonymous with M. insidiosum. However, the material of M. cylindricum from Malvinas/Falkland Islands (Stebbing 1914, p. 372; Barnard 1932, p. 244) has apparently never been revised (see Crawford 1937, p. 612,617), and M. cylindricum is currently considered as a valid species for this area (De Broyer et al. 2007, p. 241). 


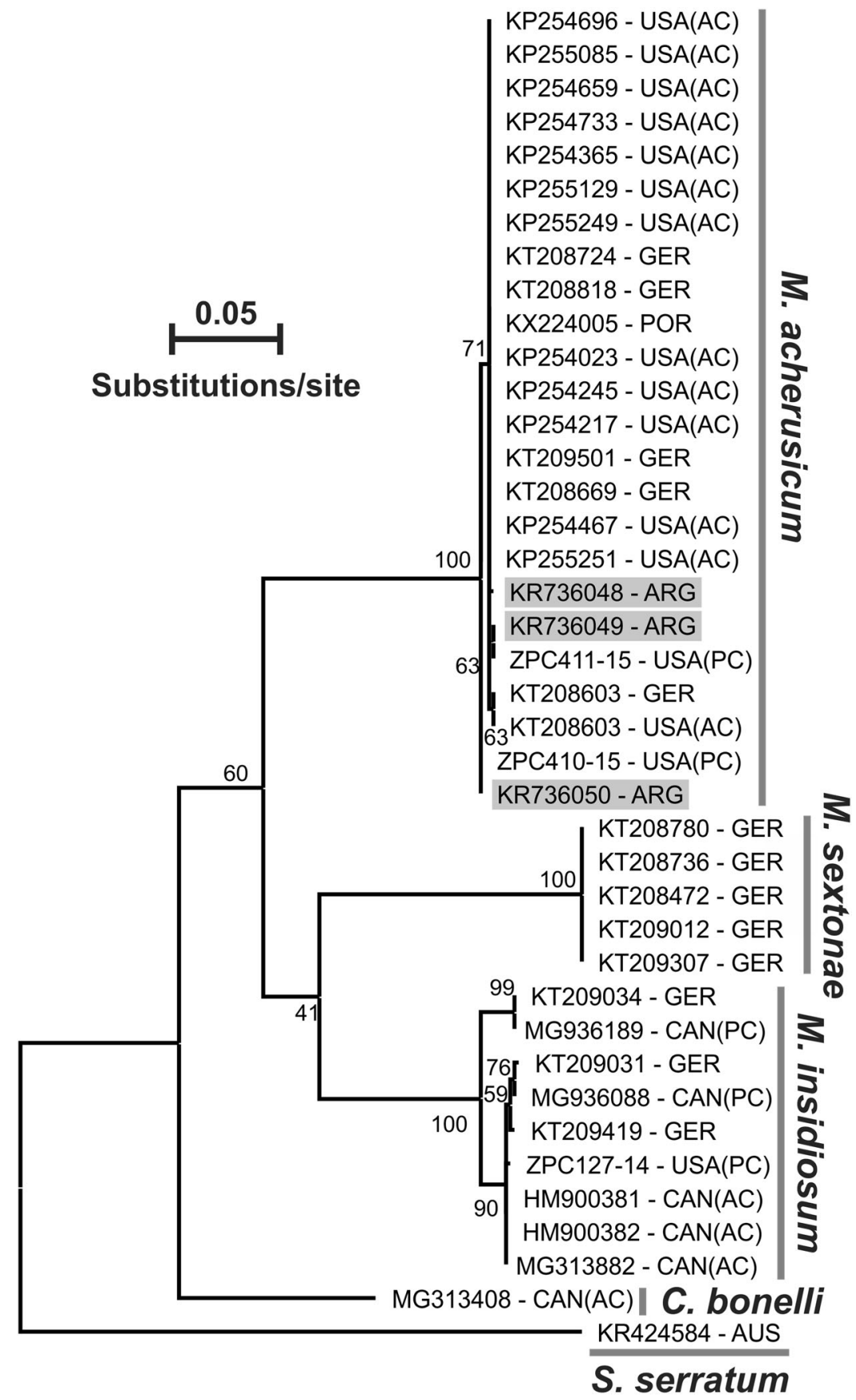

Figure 5. Maximum-likelihood phylogenetic tree of Monocorophium spp. Cytochrome c oxidase I. Specimens of Monocorophium acherusicum collected in the Mar del Plata port are marked with grey bars. Sphaeroma serratum outgroup. Abbreviations: USA, United States of America; GER, Germany; POR, Portugal; ARG, Argentina; CAN, Canada; (AC), Atlantic coast; (PC), Pacific coast. 


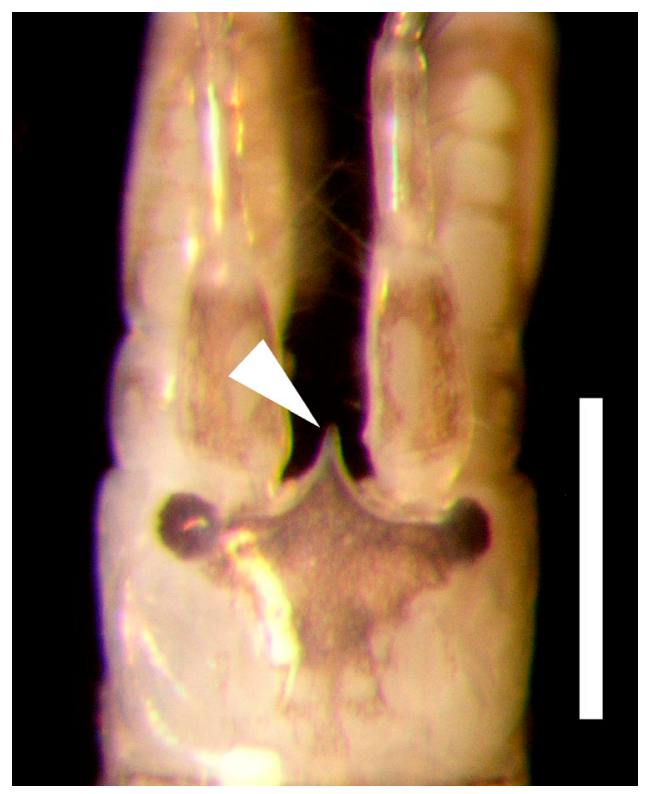

Figure 6. Rostrum of Monocorphium insidiosum, specimen collected in the Mar del Plata port. Scale bar: $0.05 \mathrm{~mm}$.

The other regional species, M. josei, differs from M. acherusicum by the following features (those of $M$. acherusicum in parentheses): antenna 1 of male, peduncular article 1 with 1 small proximal robust seta (without seta); antenna 1 of female, peduncular article 1 with 2 robust setae on dorsomedial and ventral margins respectively (3-4 robust setae on dorsomedial and 4-5 on ventral margin).

The genera Crassicorophium and Monocorophium were established by Bousfield and Hoover (1997) mainly on the basis of characters states of mandibles and gnathopod 2: Crassicorophium bearing a mandibular palp article 1 with distal process (reduced in Monocorophium), and the dactyl of gnathopod 2 with 1 tooth on posterior margin (with 2-3 teeth in Monocorophium). Despite these differences, the genera are superficially similar (Bousfield and Hoover 1997, p. 102) and certain species, especially C. bonellii, M. acherusicum and M. insidiosum, have frequently been confused (see Crawford 1937, p. 593). Some of the antennal and uropod characters normally used to identify the species of Crassicorophium and Monocorophium are closely similar in M. acherusicum and C. bonellii (see LeCroy 2004, p. 447), and the gnathopod 2 dactyl teeth numbers is too variable for species distinctions (see Chapman 2007, p. 573). In addition, males of C. bonellii have not been yet recorded (Alonso 2012), making it even more difficult the identification of both species. However, the female of $M$. acherusicum can be distinguished by the relative length of the dactyl of gnathopod 1, which it extends well beyond the palmar angle (Figure 2E), while it is not extending in C. bonellii (see Bousfiled and Hoover 1997; LeCroy 2004).

In the Magellan region, C. bonellii was first recorded in Punta Arenas and in the Beagle Channel by Schellenberg (1931), and although it has been recently mentioned from three Patagonian Atlantic ports (Comodoro Rivadavia, Puerto Deseado and Ushuaia), as well as in open waters of Rada Tilly (Chubut Province) and the Beagle Channel (see Alonso 2012; 
Schwindt et al. 2014), De Broyer et al. (2007) had already highlighted that the status of Magellan material of this species should be confirmed (see Crawford 1937, p. 612).

\section{Discussion}

Previous work on crustaceans found DNA barcoding to be a useful tool for specimen determination in both marine and estuarine amphipod species (Costa et al. 2009; Radulovici et al. 2009; Rumbold et al. 2015a). Most genetic analyses of species boundaries, especially in crustaceans, reveal the existence of cryptic species, some of which are distinguished by surprisingly large genetic differences given their morphological similarity (Palumbi and Benzie 1991; Bucklin et al. 1995; Knowlton and Weigt 1998; Sarver et al. 1998) such as corophiids (eg Monocorophium acherusicum, M. insidiosum and Crassicorophium bonellii). In the present study, we support and confirm the species identity of the invasive amphipod M. acherusicum in Mar del Plata port, using DNA barcoding.

In several studies, it has been shown that molecular analyses could be used as a tool to determine the geographic origin of invasive species and to understand the patterns and processes implied in their dispersion (Cristescu et al. 2001; Miura 2007, Makino et al. 2010). Knox et al. (2011) have shown that in their native habitat, some corophiid amphipods from discrete geographical areas presented markedly differences in their genetic lineages related with higher variation in their COI sequences. In the case of $M$. acherusicum we recorded a lower variation in this sequences between Argentina and the three widely spread locations (ie United States, Germany and Portugal), suggesting a recent introduction from a single source. However, more molecular analyses are needed in order to establish the specific geographic origin of this invasion, using not only other molecular markers (eg RNA and microsatellites), but also including specimens from other important populations, such as Japan, Australia, India, South Africa and Chile, among others.

The first record of M. acherusicum in Argentina dates from 1969 in La Lucila (36³9' S, $56^{\circ} 45^{\prime} \mathrm{W}$, Buenos Aires province, USNM \# 127701), which suggests that the species has been established in Argentina for 50 years. In the port areas, its first registry corresponds to the port of Mar del Plata in 2013 by Albano et al. (2013) and Quequén port (Albano 2012). Schwindt et al. (2014) extended the range of this species to several ports of Patagonia, indicating a rapid expansion of this species to southern South America. So far, this species has been reported mainly in port environments, suggesting that its introduction has been mainly by human-mediated vectors (eg ballast water and ship hull biofouling). Modern human-mediated dispersal of this species around the world appears to continue, M. acherusicum is found in ballast tanks after 116 days of confinement (Gollasch 2002), but also in biofouling: over 136,000 individuals, including ovigerous females were calculated to be associated with the barge fouling community, in the sub Antarctic Macquarie Island (Lewis et al. 2006). Although M. acherusicum has been recorded worldwide, due to the tendency for misidentifications among corophiid amphipods this wide distribution should be confirmed by molecular tools.

According to Albano and Obenat (2009), in the aggregates (mats) of the ecosystem engineer Phyllochaetopterus socialis Claparède, 1869, the invasive amphipod M. acherusicum (erroneously reported as $M$. insidiosum) showed higher densities mainly during summer. In this study, we registered the same pattern. Warmer temperatures can possibly accelerate growth and sexual maturity and thus encourage recruitment 
(Wilson and Parker 1996; Lee et al. 2005; Scinto et al. 2007; Beermann and Purz 2013; Rumbold et al. 2016). In colder periods, the low densities may be explained by an increased mortality and a reduced recruitment (Alonso 1984; Prato and Biandolino 2006). This pattern was similar to the observed in other peracarid species of Mar del Plata port (Kittlein 1991; Rumbold et al. 2015b, 2016). The presence of M. acherusicum in wood piles has been registered not only in Mar del Plata but also in biofouling communities of other port areas. In Los Angeles port, Barnard (1958) found that M. acherusicum dominates the biomass of the biofouling community on wooden pilings, suggesting that high density of mat-forming biofouling organisms such as corophiids (eg M. acherusicum and $M$. insidiosum) might deter the settlement of marine borers on wooden pilings. In a large-scale study in the Port of Tauranga, New Zealand, Inglis et al. (2006) recorded the introduced $M$. acherusicum from wooden piles. Also, it was recorded in the biofouling from Japan (in and around Fukuyama Harbor), commonly found at any submerged structures such as piles, pontoons, buoys, ropes of set-nets, ships' bottoms and shells of cultivating oysters or pearl-oysters (Onbe 1966).

Our results suggest that, due to the morphological similarities of $M$. acherusicum with other corophiids, the use of the DNA barcode is a significant tool for the confirmation and identity of this species in the Mar del Plata port. The combination of genetic, ecological and morphological data, allowed meaningful progress in our understanding of this ecologically important non-indigenous species. Although the ecological impacts of these species have not been considered in Southwestern Atlantic, they may compete with native organisms for food and space and in turn may act as easily accessible food items for a range of predatory fish and invertebrates, as has been shown for other invasive species (see Katsanevakis et al. 2014; Katsanevakis et al. 2016). However, more ongoing project, monitoring programmes and biological identification of native and exotic benthic invertebrates using DNA barcoding, are necessary to determine a possible impact in marine biofouling communities within the ports. Also, further studies will need in order to establish, for example, on how the origins and dispersions of these groups of crustaceans might be in the South West Atlantic ports.

\section{Acknowledgements}

We thank the Club Naútico de Mar del Plata which facilitated the access to the marinas and Ana Faigón, of Fondo iBOL Argentina, for her help with the BOLD system. We are grateful for the support provided by the Government of Canada through Genome Canada and the Ontario Genomics Institute to the International Barcode of Life Project. We would like to thank the reviewers for their critical revision of the manuscript and the suggestions received that improved the final result of this work. This funding enabled the Canadian Centre for DNA Barcoding (University of Guelph) to carry out the sequence analysis on our specimens.

\section{Disclosure statement}

No potential conflict of interest was reported by the authors.

\section{Funding}

The authors thank the Ontario Ministry of Economic Development and Innovation for funding the ongoing development of BOLD. 


\section{References}

Airoldi L, Connell SD, Beck MW. 2009. The loss of natural habitats and the addition of artificial substrata. In: Whal M, editor. Marine hard bottom communities. Heidelberg: Springer; p. 269-280.

Albano M, Obenat S. 2009. Assemblage of benthic macrofauna in the aggregates of the tubiculous worm Phyllochaetopterus socialis in the Mar del Plata harbour, Argentina. J Mar Biol Assoc UK. 89:1099-1108.

Albano MJ. 2012. Patrones de distribución y abundancia de invertebrados bentónicos exóticos en áreas naturales y portuarias de la Provincia de Buenos Aires, Argentina [dissertation]. Mar del plata: Universidad Nacional de Mar del Plata.

Albano MJ, Lana P, Bremec C, Elías R, Martins CC, Venturini N, Muniz P, Rivero S, Vallarino EA, Obenat S. 2013. Macrobenthos and multi-molecular markers as indicators of environmental contamination in a South American port (Mar del Plata, Southwest Atlantic). Mar Pollut Bull. 73:102-114.

Alonso GM. 1984. Anfípodos Gammarideos litorales del Mar Austral Argentino (Crustacea Amphipoda Gammaridea) [dissertation]. Buenos Aires: Universidad de Buenos Aires.

Alonso GM. 2012. Amphipod crustaceans (Corophiidea and Gammaridea) associated with holdfasts of Macrocystis pyrifera from the Beagle Channel (Argentina) and additional records from the Southwestern Atlantic. J Nat Hist. 29-30:1799-1894.

Barnard JL. 1958. Amphipod crustaceans as biofouling organisms in Los Angeles, Long Beach Harbors, with reference to the influence of seawater turbidity. Calif Fish Game. 44:161-170.

Barnard KH. 1916. Contributions to the crustacean fauna of South Africa. Ann S Afr Mus. 15:1-302.

Barnard KH. 1932. Amphipoda. Discovery Reports. 5:1-326.

Beermann J, Purz AK. 2013. Comparison of life history parameters in coexisting species of the genus Jassa (Amphipoda, Ischyroceridae). J Crustac Biol. 33:784-792.

Bilgin R, Utkan MA, Kalkan E, Karhan SU, Bekbolet M. 2015. DNA barcoding of twelve shrimp species (Crustacea: Decapoda) from Turkish seas reveals cryptic diversity. Mediterr Mar Sci. 16:36-45.

Bourlat SJ, Borja A, Gilbert J, Taylor MI, Davies N, Weisberg SB, Griffith JF, Lettieri T, Field D, Benzie J, et al. 2013. Genomics in marine monitoring: new opportunities for assessing marine health status. Mar Pollut Bull. 74(1):19-31.

Bousfield EL. 1973. Shallow-water gammaridean Amphipoda of New England. Ithaca (NY): Cornell University Press.

Bousfield EL, Hoover PM. 1997. The amphipod superfamily Corophioidea on the Pacific coast of North America. Part V. Family Corophiidae Corophiinae, new subfamily. Systematics and distributional ecology. Amphipacifica. 2:67-139.

Bucklin A, Frost B, Kocher T. 1995. Molecular systematics of six Calanus and three Metridia species (Calanoida: Copepoda). Mar Biol. 121(4):655-664.

Bucklin A, Wiebe PH, Smolenack SB, Copley NJ, Beaudet JG, Bonner KG, Färber-Lorda J, Pierson JJ. 2007. DNA barcodes for species identification of euphausiids (Euphausiacea, Crustacea). J Plankton Res. 29(6):483-493.

Carcedo C, Fiori S, Bremec C. 2015. Macrobenthic surf zone communities of temperate sandy beaches: spatial and temporal patterns. Mar Ecol. 36(3):326-336.

Carlton JT. 1996. Biological invasions and cryptogenic species. Ecology. 77(6):1653-1655.

Chapman JW. 2007. Amphipoda: Gammaridea. In: Carlton JT, editor. The Light and Smith manual: intertidal invertebrates from central California to Oregon. Berkeley: University of California Press; p. 545-611.

Chevreux E. 1911. Campagne de la Melita, Les amphipodes d'Algérie et de Tunisie. Memoir de la Société zoologique de France. 23:145-285.

Chevreux E. 1935. Amphipodes provenant des campagnes du Prince Albert I de Monaco. Resultats des Campagnes Scientifiques accomplies par le Prince Albert I. 90:214.

Chilton C. 1921. Some New Zealand Amphipoda. Trans Proc NZ Institute. 54:229-234. 
Cohen AN, Carlton JT. 1995. Biological study nonindigenous aquatic species in a United States Estuary: a case study of the biological invasions of the San Francisco Bay and Delta. SFEI Contribution No. 185. U.S. Fish and Wildlife Service, Washington, DC.

Conlan K. 1994. Amphipod crustaceans and environmental disturbance: a review. J Nat Hist. 28 (3):519-554.

Connell SD. 2001. Urban structures as marine habitats: an experimental comparison of the composition and abundance of subtidal epibiota among pilings, pontoons and rocky reefs. Mar Environ Res. 52(2):115-125.

Costa A. 1851. Catalogo dei crostacei italiani e di molti altri del Mediterraneo. In: Fr. Gugl. Hope, editor. Fauna del Regno di Napoli [and] Catalogo de' Crostacei del Regno di Napoli. Napoli, Azzolino; p. 44-47.

Costa A. 1853. Relazione sulla memoria del Dottor Achille Costa, di ricerche su'crostacei amfipodi del regno di Napoli. Rendiconto della Societa Reale Borbonica, Accademia delle Scienze, New Series. 2:167-178.

Costa F, Henzler C, Lunt D, Whiteley N, Rock J. 2009. Probing marine Gammarus (Amphipoda) taxonomy with DNA barcodes. Sys Bio. 7(4):365-379.

Coutts AD, Dodgshun TJ. 2007. The nature and extent of organisms in vessel sea-chests: a protected mechanism for marine bioinvasions. Mar Poll Bull. 54(7):875-886.

Crawford G. 1937. A review of the amphipod genus Corophium, with notes on the British species. J Mar Biol Assoc UK. 21(2):589-630.

Cristescu ME, Hebert PD, Witt JD, MacIsaac HJ, Grigorovich IA. 2001. An invasion history for Cercopagis pengoi based on mitochondrial gene sequences. Limnol Oceanog. 46 (2):224-229.

Dauby P, Nyssen F, De Broyer C. 2003. Amphipods as food sources for higher trophic levels in the Southern Ocean: a synthesis. In: Huiskes AAHL, Gieskes W, Rozema J, Schorno RML, Van Der Vies SM, Wolf FWJ, editors. Antarctica in a global context. Leiden: Backhuys; p. 129-134.

De Broyer C, Jażdżewski K. 1996. Biodiversity of the Southern Ocean: towards a new synthesis for the Amphipoda (Crustacea). Boll Mus Civ Stor Nat Verona. 20(1993):547-568.

De Broyer C, Lowry J, Jazdzewski K, Robert H. 2007. Catalogue of the Gammaridean and Corophiidean Amphipoda (Crustacea) of the Southern Ocean with distribution and ecological data. In: De Broyer C, editor. Census of Antarctic marine life: synopsis of the Amphipoda of the Southern Ocean. Bull Inst R Sc N B Biologie. 77:1-325.

Della Valle A. 1893. Gammarini nel Golfo di Napoli. Monografien zur Flora und Fauna des Golfes von Neapel. 29:1-948.

Floerl O, Inglis GJ. 2003. Boat harbour design can exacerbate hull fouling. Austral Ecol. 28 (2):116-127.

Folmer M, Black M, Hoeh W, Lutz R, Vrijenhoek R. 1994. DNA primers for amplification of mitochondrial cytochrome $\mathrm{c}$ oxidase subunit I from diverse metazoan invertebrates. Mol Mar Biol Biotechnol. 3(5):294-299.

Glasby TM. 1999. Differences between Subtidal Epibiota on Pier Pilings and Rocky Reefs at Marinas in Sydney, Australia. Estuar Coast Shelf Sci. 48(2):281-290.

Godwin LS. 2003. Hull fouling of maritime vessels as a pathway for marine species invasions to the Hawaiian Islands. Biofouling. 19:123-131.

Gollasch S. 2002. The importance of ship hull fouling as a vector of species introductions into the North Sea. Biofouling. 18:105-121.

Griffiths C, Mead A, Robinson T. 2009. A brief history of marine bio-invasions in South Africa. Afr Zool. 44(2):241-247.

Hall TA. 1999. BioEdit: a user-friendly biological sequence alignment editor and analysis program for Windows 95/98/NT. Nucleic acids symposium series; 1999: [London]: Information Retrieval Ltd., c1979-c2000.

Hayes K, Sliwa C, Migus S, McEnnulty F, Dunstan P, Heritagearkes P. 2005. National priority pests. Part II, Ranking of Australian marine pests. Australian Government Department of the Environment and Heritage: Parkes. http://www.environment.gov.au/system/files/resources/ 02d33408-ad61-4d11-b5a4-6bf1aa333776/files/priority2.pdf 
Hewitt CL, Campbell ML, Thresher RE, Martin RB, Boyd S, Cohen BF, Currie DR, Gomon MF, Keough MJ, Lewis JA, et al. 2004. Introduced and cryptogenic species in Port Phillip Bay, Victoria, Australia. Mar Biol. 144(1):183-202.

Hirayama A. 1995. Gammaridea. In: Nishimura S, editor. Guide to seashore animals of Japan with color pictures and keys, Volume II. Osaka: Hoikusha; p. 173-193.

Hou Z, Fu J, Li S. 2007. A molecular phylogeny of the genus Gammarus (Crustacea: Amphipoda) based on mitochondrial and nuclear gene sequences. Mol Phylogenet Evol. 45(2):596-611.

Ieno E, Bastida R. 1998. Spatial and temporal patterns in coastal macrobenthos of Samborombon Bay, Argentina: a case study of very low diversity. Estuaries Coasts. 21(4):690-699.

Inglis G, Gust N, Fitridge I, Floerl O, Woods C, Hayden B, Fenwick G. 2006. Port of Tauranga. Baseline survey for non-indigenous marine species (Research Project ZBS2000/04). Wellington: Biosecurity New Zealand. Technical Paper No.: 2005/05.

Irie H. 1956. Tube-building amphipods occurring at the 'Wakame' (A species of brown algae Undaria pinnatifida) grounds of Simabara, Nagasaki prefecture. Bull Fish Nag Univ. 4:1-6.

Ivanova NV, Dewaard JR, Hebert PD. 2006. An inexpensive, automation-friendly protocol for recovering high-quality DNA. Mol Ecol Resour. 6(4):998-1002.

Katsanevakis S, Wallentinus I, Zenetos A, Leppäkoski E, Çinar ME, Oztürk B, Grabowski M, Golani D, Cardoso AC. 2014. Impacts of invasive alien marine species on ecosystem services and biodiversity: a pan-European review. Aquat Invasions. 9:391-423.

Katsanevakis S, Tempera F, Teixeira H, Bode M. 2016. Mapping the impact of alien species on marine ecosystems: the Mediterranean Sea case study. Divers Distrib. 22(6):694-707.

Kerckhof F, Haelters J, Gollasch S. 2007. Alien species in the marine and brackish ecosystem: the situation in Belgian waters. Aquat Invasions. 2(3):243-257.

Kittlein MJ. 1991. Population biology of Sphaeroma serratum Fabricius (Isopoda, Flabellifera) at the Port of Mar del Plata, Argentina. J Nat Hist. 25(6):1449-1459.

Knowlton N, Weigt LA. 1998. New dates and new rates for divergence across the isthmus of Panama. Proceedings of the Royal Society of London B: Biological Sciences. 265(1412):22572263.

Knox MA, Hogg ID, Pilditch CA. 2011. The role of vicariance and dispersal on New Zealand's estuarine biodiversity: the case of Paracorophium (Crustacea: Amphipoda). Biol J Linn Soc. 103 (4):863-874.

Kuris AM, Culver CS. 1999. An introduced sabellid polychaete pest infesting cultured abalones and its potential spread to other California gastropods. Invertebr Biol. 118:391-403.

LeCroy S. 2004. An illustrated identification guide to the nearshore marine and estuarine Gammaridean Amphipoda of Florida, Volume 3, families Bateidae, Biancolinidae, Cheluridae, Colomastigidae, Corophidae, Cyproideidae and Dexaminidae. Florida (FL): Department of Environmental Protection.

Lee JS, Lee KT, Kim DH, Kim CK, Lee JH, Park KH, Park GS. 2005. Application of indigenous benthic amphipods as sediment toxicity testing organisms. Ocean Sci J. 40(1):17-24.

Lewis PN, Bergstrom DM, Whinam J. 2006. Barging in: a temperate marine community travels to the subantarctic. Biol Invasions. 8(4):787-795.

Lincoln R. 1979. British marine amphipoda: Gammaridae. London: British museum (Natural History).

López Gappa J, Alonso GM, Landoni NA. 2006. Biodiversity of benthic Amphipoda (Crustacea: Peracarida) in the Southwest Atlantic between $35^{\circ} \mathrm{S}$ and $56^{\circ} \mathrm{S}$. Zootaxa. 1342:3-66.

Makino W, Knox M, Duggan IC. 2010. Invasion, genetic variation and species identity of the calanoid copepod Sinodiaptomus valkanovi. Freshwater Biol. 55:375-386.

Martin JP, Garese A, Sar A, Acuña FH. 2015. Fouling community dominated by Metridium senile (Cnidaria: Anthozoa: Actiniaria) in Bahía San Julián (Southern Patagonia, Argentina). Sci Mar. 79(2):211-221.

Miura O. 2007. Molecular genetic approaches to elucidate the ecological and evolutionary issues associated with biological invasions. Ecol Res. 22(6):876-883.

Molnar JL, Gamboa RL, Revenga C, Spalding MD. 2008. Assessing the global threat of invasive species to marine biodiversity. Front Ecol Environ. 6(9):485-492. 
Neves CS, Rocha RM, Pitombo FB, Roper JJ. 2007. Use of artificial substrata by introduced and cryptogenic marine species in Paranaguá Bay, southern Brazil. Biofouling. 23(5-6):319-330.

Neves CS, Rocha RM. 2008. Introduced and cryptogenic species and their management in Paranaguá Bay, Brazil. Braz Arch Biol Technol. 51(3):623-633.

Noël PY. 2011. Checklist of cryptogenic and alien crustacea of the European Atlantic coast. In: Bella S Galil, Clark PF, Carlton JT, editors. The wrong place-alien marine crustaceans: distribution, biology and impacts. Dordrecht: Springer; p. 345-375.

Nuñez Velazquez S, Rumbold CE, Obenat SM. 2017. Population dynamics of Caprella dilatata and Caprella equilibra (Peracarida: Amphipoda) in a Southwestern Atlantic harbour. Mar Biol Res. 3 (8):888-898.

Olden JD, Poff N. 2004. Ecological processes driving biotic homogenization: testing a mechanistic model using fish faunas. Ecology. 85(7):1867-1875.

Onbe T. 1966. Observations on the tubicolous amphipod, Corophium acherusicum Costa, in Fukuyama harbor area. J Fac Fish Anim Husb Hiroshima Univ. 6:323-338.

Orensanz JML, Schwindt E, Pastorino G, Bortolus A, Casas G, Darrigran G, Elías R, Gappa JJL, Obenat S, Pascual M, et al. 2002. No longer the pristine confines of the world ocean: a survey of exotic marine species in the southwestern Atlantic. Biol Invasions. 4(1-2):115-143.

Palumbi SR, Benzie J. 1991. Large mitochondrial DNA differences between morphologically similar penaeid shrimp. Mol Mar Biol Biotechnol. 1(1):27-34.

Prato E, Biandolino F. 2006. Life history of the amphipod Corophium insidiosum (Crustacea: Amphipoda) from Mar Piccolo (Ionian Sea, Italy). Sci Mar. 70(3):355-362.

Radulovici AE, Sainte-Marie B, Dufresne F. 2009. DNA barcoding of marine crustaceans from the estuary and Gulf of St Lawrence: a regional-scale approach. Mol Ecol Resour. 9(s1):181-187.

Reise K, Gollasch S, Wolff WJ. 1998. Introduced marine species of the North Sea coasts [journal article]. Helgoländer Meeresuntersuchungen. 52(3):219-234.

Rivero MS, Elías R, Vallarino EA. 2005. First survey of macroinfauna in the Mar del Plata Harbor (Argentina), and the use of polychaetes as pollution indicators. Rev Biol Mar Oceanogr. 40 (2):101-108.

Ruiz GM, Fofonoff PW, Carlton JT, Wonham MJ, Hines AH. 2000. Invasion of coastal marine communities in North America: apparent patterns, processes, and biases. Annu Rev Ecol Evol Syst. 31(1):481-531.

Ruiz G, Fofonoff P, Steves B, Dahlstrom A. 2011. Marine crustacean invasions in North America: a synthesis of historical records and documented impacts. In: Bella S Galil, Clark PF, Carlton JT, editors. The wrong place-alien marine crustaceans: distribution, biology and impacts. Dordrecht: Springer; p. 215-250.

Rumbold CE, Obenat SM, Spivak ED. 2015a. Comparison of life history traits of Tanais dulongii (Tanaidacea: Tanaididae) in natural and artificial marine environments of the south-western Atlantic. Helgol Mar Res. 69(2):231-242.

Rumbold C, Lancia J, Vázquez G, Albano M, Farias N, Moyano MPS, Spivak E, Obenat S. 2015b. Morphological and genetic confirmation of Jassa slatteryi (Crustacea: Amphipoda) in a harbour of Argentina. Mar Biodivers Rec. 8:e37.

Rumbold CE, Barlett TR, Gavio MA, Obenat SM. 2016. Population dynamics of two invasive amphipods in the Southwestern Atlantic: Monocorophium acherusicum and Ericthonius punctatus (Crustacea). Mar Biol Res. 12(3):268-277.

Sarver SK, Silberman JD, Walsh PJ. 1998. Mitochondrial DNA sequence evidence supporting the recognition of two subspecies or species of the Florida spiny lobster Panulirus argus. J Crustacean Biol. 18(1):177-186.

Say T. 1818. An account of the crustacea of the United States. J Acad Nat Sci Phila. 1:445-458.

Schellenberg A. 1928. Zoological results of the Cambridge expedition to the Suez Canal, 1924. 35. Report on the Amphipoda. Trans Zool Soc London. 22:633-692.

Schellenberg A. 1931. Gammariden und Caprelliden des Magellangebietes, Südgeorgiens und der Westantarktis. Further Zoological Results of the Swedish Antarctic Expedition 1901-1903. 2:1-290.

Schultheiss JAP. 2009. Composición y diversidad de la fauna de Amphipoda (Crustacea, Peracarida) asociada a instalaciones acuícolas de Bahía Metri, región de los lagos, Chile. 
Informe Final. [accessed 2018 Mar 23]. https://centroestudiosbiodiversidad.files.wordpress.com/ 2009/08/informe_amphipoda_metril.pdf

Schwindt E, López Gappa J, Raffo MP, Tatián M, Bortolus A, Orensanz JM, Alonso G, Diez ME, Doti B, Genzano G, et al. 2014. Marine fouling invasions in ports of Patagonia (Argentina) with implications for legislation and monitoring programs. Mar Environ Res. 99:60-68.

Scinto A, Benvenuto C, Cerrano C, Mori M. 2007. Seasonal cycle of Jassa marmorata Holmes, 1903 (Amphipoda) in the Ligurian Sea (Mediterranean, Italy). J Crustacean Biol. 27(2):212-216.

Shoemaker CR. 1934. Two new species of Corophium from the West Coast of America. J Wash Acad Sci. 24:356-360.

Shoemaker CR. 1947. Further notes on the amphipod genus Corophium from the East Coast of America. J Wash Acad Sci. 37:47-63.

Sivaprakasam TE. 1970. Amphipoda from the East Coast of India. Part. 2. Gammaridea and Caprellidea. Bombay Natural History Society. 6-7(2):153-170.

Stebbing TRR. 1906. Amphipoda. I. Gammaridea. DasTierreich. 21:1-806.

Stebbing TRR. 1914. Crustacea from the Falkland Islands collected by Mr. Rupert Vallentin, F.L.S. Part II. Proc Zool Soc London. 1914:341-378.

Sueiro MC, Bortolus A, Schwindt E. 2012. The role of the physical structure of Spartina densiflora Brong in structuring macroinvertebrate assemblages. Aquat Ecol. 46(1):25-36.

Tamura K, Stecher G, Peterson D, Filipski A, Kumar S. 2013. MEGA6: molecular evolutionary genetics analysis version 6.0. Mol Biol Evol. 30(12):2725-2729.

Thiel M, Gutow L. 2005. The ecology of rafting in the marine environment. I. The floating substrata. Oceanography and Marine Biology: an Annual Review. 42:181-264.

Thiel M, Hinojosa I. 2009. Peracarida-Anfípodos, Isópodos, Tanaidáceos \& Cumáceos. In: Häussermann V, Förstera E, editors. Fauna Marina Bentónica de la Patagonia Chilena: guía de indentificación ilustrada. Santiago de Chile: Nature in Focus; p. 671-738.

Thompson JD, Higgins DG, Gibson TJ. 1994. CLUSTAL w: improving the sensitivity of progressive multiple sequence alignment through sequence weighting, position-specific gap penalties and weight matrix choice. Nucleic Acids Research. 22:4673-4680.

Underwood AJ. 1997. Experiments in ecology: their logical design and interpretation using analysis of variance. Cambridge (UK): Cambridge University Press.

Valério-Berardo MT, De Souza AMT. 2009. Description of two new species of the Corophiidae (Amphipoda, Crustacea) and register of Laticorophium baconi (Shoemaker, 1934) from Brazilian waters. Zootaxa. 2215:55-68.

Walker AO. 1909. No. XVIII. Amphipoda gammaridea from the Indian Ocean, British East Africa, and the Red Sea. Trans Linnean Society of London. 12:323-344.

Wasson K, Zabin CJ, Bedinger L, Cristina Diaz M, Pearse JS. 2001. Biological invasions of estuaries without international shipping: the importance of intraregional transport. Biol Conserv. 102 (2):143-153.

Wilson WH, Parker K. 1996. The life history of the amphipod, Corophium volutator: the effects of temperature and shorebird predation. J Exp Mar Bio Ecol. 196(1-2):239-250. 